\title{
POPULAR PIETY AND THE MUSLIM MIDDLE CLASS BOURGEOISIE IN INDONESIA
}

\author{
Lukis Alam \\ Graduate School of UIN Sunan Kalijaga, Yogyakarta \\ Lecturer Of Islamic Religious Education (PAI) at STTNAS, Yogyakarta \\ Email: lukisalam@gmail.com
}

\begin{abstract}
This paper discusses the passion of Islamization of the New Order, at the same time the mainstream of this power is based on economic development that provides opportunities for the growth of the Muslim middle class. Patronage model used by the New Order gives an indication that the power built by this regime wants to instill a strong influence in society. At the same time, the New Order is depoliticizing the political attitudes of Muslims. This has implications for the marginalization of the interests of Muslims on the national stage. In this study will also be affirmed the influence of the New Order's power on the presence of the Muslim middle class. On the one hand their birth was the result of the economic development that the New Order echoed. On a different aspect, the presence of the middle class gives strong legitimacy that they are part of the dominating class structure in a country. Also will be reviewed about middle-class interference with the trend of Islamic populism that actually occurred in the era of the 80s, but re-spread after post-reform. Popular Islamic culture becomes a trend that spread through various media such as, internet, magazines, newspapers and so forth. This has received considerable response from middle-class Muslims and led to commodification. Religion facilitates to interact with modernity. Materialistic and hedonistic interests intersect with obedience in the practice of religion. On the one hand, the mode of consumption of the Muslim middle class changes with the adaptation of piety values in the public sphere.
\end{abstract}

Keywords: Popular, Islam, piety, middle class, bourgeoisie, Indonesia

\section{INTRODUCTION}

The early birth of the New Order regime was motivated by a very complex economic and political crisis. The national economy at that time was in a very poor condition. As Harold Crouch described, in 1965 inflation reached 500 percent, and rice prices soared 900 percent (Crouch,1986:67). It started on March 11, 1966 when he succeeded President Sukarno. With the current support of ABRI (Indonesian Armed Forces), Soeharto stabilized the direction 
of domestic political policy by controlling almost all aspects of government including economic, political, social aspects creating good economic growth and domestic stability ( Vatikiotis, 1993: 1, ix-x).

In the unfavorable economic and political situation, whoever leads should prevent the crisis from getting worse by implementing a strategy of political and economic stability. Soeharto with all his convictions convinced the people that the new regime he built was the legitimate and constitutional heir of President Sukarno. According to Salim Said (2016:10), Seoharto's capital actually comes to power in addition to harnessing military power. He used the "anger" of the people in the communist party (PKI). He realized that despite his lack of charisma and political experience over his predecessors, but with a keen sense of power instinct, Suharto was sure his rule would be lasting. The political reference used by Soerharto is free-active, which tends to follow America. The New Order's interest in the aspects of economic development altered Suharto's view of western capitalism. In addition to the economic issues that became the jargon of the New Order, domestic politics of Suharto's main concern also needed attention. Some countries that become relations of Indonesia such as, Autralia, Japan and other Asian countries get special attention. On the other hand, the New Order's strong desire to develop the national economy, and the welfare of the people's life, are characteristic of this regime (Ricklefs,2008: 587-589).

\section{DEPOLITICIZING THE REGIME AGAINST MUSLIMS}

The authoritarianism adopted by the New Order received the attention of Saiful Mujani, by adopting some western scholars opinions such as Anderson (1972) which explains that because Suharto was a man of Javanese tradition, the source of authoritarianism that he embraced came from Javanese political culture which did not recognize democracy. Another case with Samson (1973), in fact the modernist Muslim elite has a strong fighting spirit for the Islamization of the country. However, on the other hand it does not seem to get a good reception on the power elite so that it has a difficulty in realizing a moderate political climate during the New Order (Mujani, 2007:30).

The Muslim's desire to re-take does not seem to be welcome, Soerharto not only got rid of the PKI but also removed the Muslims. This is based on the unilateral interests of the New Order in running the government, the background of Suharto who is an abangan Islam and a worldview against Islam gives influence to the model of government that it runs (Hefner \& Horvatich,1997: 77-79). So that Muslims suspect that the New Order government has been infiltrated by certain parties who aim to achieve the hidden interests (Hefner 
\& Horvatich,1997: 77-79). Considering the reading of Ariel Heryanto, the Soeharto government is rich in sharing political maneuvers that tend to be patrimonalism (Heryanto \& Mandal, 2003: 4-5).

Since the beginning of 1966, Soeharto's desire to obstruct the wishes and aspirations of Muslims is clear. The perception of the New Order regime when the country wanted to be built using Islamic conceptions. The failure of Masyumi leaders to rehabilitate his own party and other wishes such as the application of Islam as the basis of the state; the wishes of former Vice President Mohammad Hatta along with the HMI exponents and the PII established the PDII (Partai Demokrasi Islam Indonesia Indonesia) party; aspirations of Muhammadiyah leaders to reactivate the PII party (Partai Islam Indonesia) were strongly banned by the New Order regime. Even more frontal, Suharto with his "hands-on" politics suppressed radical Islamic groups potentially against the government (Alfian,1980:2-3).

The gait of Muslims in the political arena from the Old Order to the New Order experienced ups and downs. The tendency of the New Order to conduct political bureaucracy with the emasculation of the aspirations of Muslims seems to be a shortcut done. So that gave birth to a new awareness among Muslims that the political field is not the right path (Tebba, 1993: 4-5). The fear of the New Order with Islam according to Din Syamsudin is an attempt to depolitise and desbolize Islam. This is an attempt to get rid of Islamic symbols from the political stage, the elimination of Islamic ideological parties ( Syamsuddin,2001:66-68). The large project implemented by the New Order wants to remove the awareness and attention of the underclass and deliberately alienate their leaders from the frenetic atmosphere that carries a critical pattern of Islam towards the state.

Suharto considers the political parties to be the source of the chaos and political instability that had occurred in the period of liberal democracy. This is what underlies Soeharto's "nervousness" towards political parties. Suharto's actions were regarded as an intervention in the bureaucracy of political parties, including Islamic parties (Crouch,1986:276). The New Order's treatment of Islam gained the attention of scholars, one of whom was Hamka (Haji Abdul Karim Amrullah) a modernist from West Sumatra. He criticized the New Order regime for putting forward national development and economic strengthening but did not take into account the moral and ethical aspects of society. When religion is kept out of society, the resulting effect destroys the social order. He is a brave cleric that the New Order regime has legalized prostitution and gambling because it is easier to sell and the benefits gained (Bourchier \&Hadiz,2014: 83). 
When the state can control religion, the phenomenon that occurred during the New Order according to Schwarz (1999) in the reading of Robert W. Hefner, "Islam is seen as a safe alternative to a very strict political structure" (Hefner,2000:5-6). Although the penetration of the New Order against Islamic parties is so strict, anyone can engage in public spheres but is restricted by strict rules. For example, in 1978 the government began to impose restrictions on organizing campus politics. Then in the years 1984-1985 the government required religious organizations and mass organizations to incorporate Pancasila ideology into its articles of association, if it refused the regime would make a ban.

Toward the end of the 1980s the tension between Muslims and the New Order began to improve, Suharto no longer worried about Islam. Although at the beginning of the New Order period, Islam was seen as political enemy number two after the communist (Anwar,2009: 355). The openness of Suharto's attitude toward Islam is reflected in the ratification of educational law, which includes clauses of every public school should provide religious instruction to his students, establish the Law of Religious Courts, establish Board of Zakat, Infak and Sedekah (BAZIS), for female students in public schools are allowed to wear the hijab (An-Na'im, 2007:437). This period of establishment of various institutions increasingly vibrant, ranging from the integration of Islamic education into the system of public education, the establishment of ICMI by B.J Habibie, establishment of Muamalat bank as the first Islamic bank in Indonesia and the Bank of Credit Sharia and so on (Azra,2006:12).

\section{PROSPERITY, ISLAMIC BOURGEOISIE, AND THE APPEARANCE OF MIDDLE CLASS MUSLIMS}

The appearance of the New Order as a supporting deity in the era of the early 1960s over the leadership of the Old Order which at that time was ostracized by the United States, European countries and Japan provided opportunities for the New Order to display its "power" in saving Indonesia at that time. At the end of Seokarno's leadership, Indonesia was plagued by a very severe poverty that had an impact on the slow pace of domestic economic growth. To create development stability which has an impact on creating stable economic stability, at least the New Order uses the concept of Development Trilogy: (1) Economic growth; (2) Political stability; (3) Equity. These three things are the foundation for the New Order's economic technocrats supporting the regime at that time. Furthermore, this ekomini growth can be well established when political stability is achieved perfectly. Therefore, to create a good economic stability is entrusted to the military. So that economic and military technocrats 
into a dual-world vehicle that can not be separated (Budiman,2002:21).

The power of the New Order which always prioritized the economic and political sector development strategies contributed to the creation of Indonesia's domestic conditions. The New Order claimed that the power he created was called a domestic stabilizer and dynamizer that had unlimited control functions. This is addressed by the New Order as a task that has been mandated by the state ideology of Pancasila in bringing prosperity to the people of Indonesia (Rinakit,2005:27-29). On the other hand, the New Order's patrimonalism is so strongly exploit the patron relationship between subordinates and superiors. Political isolation is used to avoid political influence from outside the loyalists. This patrimonial policy is used to protect the power that has been institutionalized (Aspinall:2005,132).

At the time of the Old Order came to power, the people felt lied to by the accommodating of communist interests in the government. By Max Weber this patrimonial model was introduced as a term to explain how a ruler governs wealth and power based on traditional authority, not based on a system of rule of law and order (Aspinall:2005,133-136). Suharto was able to maintain this patrimonial model well until near the end of his rule in 1998. Patrimonialism is also called by Van Leur as a political capitalism or trade capitalism that wants to benefit certain parties, this can be a synthesis of the culture of patrimonialism adopted by the New Order. The state plays an important role in various sectors such as food production, education, public infrastructure and so on (Amir,2013:35).

John Meuleman describes the liberalization and economic globalization that took place in Indonesia as the New Order regime that began in the late 1970s had an impact on improving the economic condition of the Muslim population as a whole. In the late 1980s an increasing number of Muslim communities were able to perform Hajj and after that Indonesia was known as the country that sends the world's largest pilgrims outside of Saudi Arabia. Throughout that era mosque construction has mushroomed everywhere; the establishment of majlis taklim residing in luxury hotels and so on, as well as the development of Islamic schools and pesantren in urban areas. The rate of economic growth contributes to the increasing number of middle-class Muslims, of whom they are able to go abroad, and many also take part in social, political, and economic performances. So they become a symbol of the middle class establishment (Azra in Meuleman,2002:25).

This regime is smart enough to grasp the opportunities that make political stability necessary to overcome the backwardness of economic development. In such a situation the state benefits from the presence of the middle class 
who sometimes becomes anti-system sponsors, so controlling the middle class means controlling state stability (Denny,2006:33). The opposite situation will occur when the development of the economic sector cannot be read well by the state which has an impact on economic instability and social inequality. Of course Indonesia as a Muslim-majority country has an interest in adjusting the conditions and situations that cause the appearance of the Muslim middle class in public areas (Burhanuddin, 2013:179).

On the other hand, because the middle class is pseudo, sometimes difficult to see as part of social-political-cultural structure of Indonesian society. However, if it is agreed that the definition of the middle class from the economic aspect with all its diversity is through the consumption pattern (Dick in Tanter,1990: 64). Solvay Gerke explained that the consumption pattern of the middle class has changed from meeting basic needs (basic needs fulfilled approach) to meeting the needs of symbols, status and lifestyle (symbolic consumption approach). Therefore, the shift in the pattern of consumption fulfillment is not based on needs, but rather to strengthen the status of the class that prioritizes secondary and tertiary needs (Gerke in Huat, 2000:135:158).

\section{TRENDY, POPULAR PIETY: MUSLIM MIDDLE CLASS IDENTITY AFTER THE FALL OF SOEHARTO}

After ICMI was well instituted with the election of B.J Habibie as chairman, there was an interesting phenomenon after that in 1991 to coincide with the 70th anniversary of Suharto performing the pilgrimage and his extended family. This was a public concern, for Suharto this was the first time he went on pilgrimage. He is often regarded as an abangan Muslim, thick with the practice of kejawen which is far from Islamic Orthodoxy and not so religious. Coming back from Makah, in addition to the title of Hajj, he added the name of Muhammad as a symbol that he was trying to be a pious Muslim. There is a growing assumption, when Suharto was elderly (growing older in Javanese terms) he increased his religiosity rather than before (Barton, 2008:218). Another opinion stated that Suharto's departure to the holy land was considered a political act designed to convey a message to conservative santri Muslims from now on he could be a trustworthy person and with him they could work together. The truth is that since 1987 he has been thinking about embracing conservative Muslims who are used as a political counterweight other than the military (Barton, 2008:218). Later, Suharto's trend was imitated by the middle class to perform Hajj and Umrah with luxury or plus facilities (Mufid, 2006:269).

Things that need attention also regarding the dynamics of economic growth 
affect the process of mobility of certain community structures. In this case it is the class of santri to the higher grade class. They were previously a group based on the rural environment. They then migrated to the city, becoming an educated middle class that filled big cities like Jakarta, Bogor, Bandung, Yogyakarta, Surabata, Padang, Medan, Ujung Pandang and so on. Which by Giddens, they are classified as middle class people who do not enjoy the property in the means of production, but belong to those who have the qualifications of education, skills, and technological skills (Hasbullah,2017: 112-116). Political dynamics in Indonesia after the fall of Soeharto era in the early 2000s, at that time Abdurrahman Wahid issued Inpres No.6 of 2009 which instructed the permissibility of ethnic Chinese to organize religious activities. The impact of this Presidential Instruction on Chinese society has the opportunity and freedom to carry out their religious activities. The Chinese New Year celebration is prohibited, with the Inpres every year they are free to celebrate and also affect the actualization of religious freedom in general.

In the midst of shock situations that test the existence of religious in Indonesia as described above, emerged a more universal and modern Islamic expression. Muslim Preacher's Abdullah Gymnastiar who is more familiarly called with Aa Gym has nourished the da'wah content that can be accepted by the wider community. The concept of qolbu management popularized has brought a new da'wah model in the community. Not only did the Muslim community accept their da'wah, the non-Muslim community also received the da'wah that they carried. In addition, Ary Ginanjar Agustian also appeared with his ESQ (Emotional Spiritual Questient). The idea that he stretches integrates the concept of modern Islam that can be accepted by all circles. The training he held extended to all people, especially the upper middle class. In every training he held, he always set costs up to millions of rupiah. The combination of Islamic character with Western spiritual management is the hallmark of Ary Ginanjar in every session (Agustian, 2016).

The rise of national films became the spirit of displaying Islamic film identity. After the reforms, films were filmed by young filmmakers such as Hanung Bramantyo (2008) in his film "Ayat-Ayat Cinta" (2008), "Wanita Berkalung Sorban” (2009), “Sang Pencerah” (2010), then Chaerul Umam’s work “ Ketika Cinta Bertasbih “(2009). The films are making tremendous profits and are very popular among Muslims. The films are adapted from the novel by Habiburrahman el-Shirazzy, so that the characters raised into the films are a struggle between Muslim identity and piety that is becoming a trend, and is favored by young people. In addition, the existence of these films became social criticism and became anti-theses to the onslaught of Westernized 
popular culture. And the filmmakers want to prove that Islam can synergize with modernization without having to leave the foundation of its teachings (Sasono in Daniels,2013:45-69). Religious music also enlivened the popular market, which in fact the early generation of religious music was seen in the Bimbo era in the 80 s which incorporated the kasidah and gambus models into pop music. In 2004 the beginning of the Gigi music group released the album Raihlah Kemeaengan, which combined rock lyrics with religious lyrics. After that began to appear religious songs from various music bands such as, Ungu, Wali, Nidji, ST 12, Radja, and Coklat.

The non-educational spectacle is the reason for the creators to display the messages of Islam in the soap opera. The characterization of a pious person (shaleh) becomes the main topic in its cultivation, no longer highlight scenes such as relations between men and women who are not mahram, which looks at soap operas in general. Such symbols would present a popular culture of piety to the center of society, which would later become a populist alternative in the Muslim community (Subijanto,2013:73-86). ${ }^{1}$ In addition, Muslim fashion trends and Muslim magazines are increasingly diverse, such as Annida, Muslimah, Scarf, MusMagz, Alisha, Hijabella, Paras and so on. In addition to the emergence of an Islamic band (nasyid) inspired by overseas bands, they sang religious songs. Widespread salons are reserved for Muslim women, then the Hajj and Umroh Bureau, whose customers come from the urban middle class. Certainly in contrast to the lower-class, they have to register the hajj through the government. For Jean Gelman, the phenomenon fosters capitalism and showcased commercialism, reinforcing the identity of the middle class based on their religious experience (Taylor, 2013:181).

The mid-2000s social media revolution was so rapid, with the birth of Facebook (2004), Flickr (2004), BlackBerry Messenger (2005), Twitter (2006), WhatsApp (2009), Instagram (2010). The wide range of social media options has an impact on Muslim middle-class expression to their social environment. Until finally the development of smartphones using Android (2008) became the choice of the middle class which until 2016 the total downloads from the Google Play application reached 65 billion. The digital revolution does not stop there, but there are still new players. Gojek who stood in 2010 became a pioneer ojek online in Indonesia. Its success in 2015 has inspired similar services into Indonesia such as, Grab and Uber that established itself as a mass

${ }^{1}$ After the fall of Soeharto's rule, many television shows displayed a pious identity as part of popular culture. This cannot be separated from the changing situation in placing Islam as a post-Soeharto cultural and political arena. On the other hand, the rise of Islamic shows on television as an interpretation of the creators to offer quality shows as a "form of resistance" to the influence of Western popular culture. Islamic television shows how religious discourse in public sphere, at the same time triggers popular piety in public sphere. 
service that so rapidly.

The shift of middle-class orientation of Muslims after the fall of the New Order created its own dynamics. In addition to the emergence of a variety of popular cultures that influence the Muslim middle-class perspective, the change in the mode of religiosity affects their behavior. Increased religiosity is not only visible in the worship performed. In consuming any product they pay attention to the functional and emotional benefits of a product. In addition they also care about the spiritual benefits of the product. Their knowledgeable and technology-savvy dominance combines with the growing understanding of religiosity that when they consume or intersect with various products must be in line with compliance with Islamic values and teachings. This is in contrast to the West, as they move forward, the more secularized they do not even believe in the existence of God (Yuswohadi, 2012). The compliance of the Muslim middle class in carrying out the teachings of Islam by placing the elements of religiosity is not merely a desire, but it becomes manifest in obeying God's command and away from His prohibitions. In consuming products and services, not just seek functional and emotional benefits like before. Spiritual benefits become part of the "enable" in their lives, especially in strengthening Islam and belief in Allah SWT.

\section{CONCLUSION}

The awareness of the Muslim middle class towards the symbols of Islam that are trying to be shown to the public sphere is followed by a shift in their Islamic orientation which is based on the process of new model Islamization. However, in different aspects the emergence of the Muslim middle class also results in changes in the mode of consumption of society. Such phenomena cannot be denied, because commodification in public space has become a necessity. The New Order, which had been in power for years, was not enough to arouse optimism for the Muslim middle class. In the beginning their efforts in contesting national politics were hampered by the regime. Later, when the New Order rule was over they were given the opportunity to take part in various fields. Popular Islamic culture is present as part of reculturation of Islam in the public sphere. This is as a resistance to Western culture which is feared to damage the nation. Therefore, the effort to display modern piety has always been the routine of the Muslim middle class in negotiating with globalization. 


\section{BIBLIOGRAPHY}

Agustian, A. G. (2016). Revolusi Mental Berbasis ESQ. Jakara: Arga Tilanta.

Amir, S. (2013). The Technological State in Indonesia: The Constitution of High Techonlogy and Authorian Politics. UK: Routledge.

An-Na'im, A. A. (2007). Islam Dan Negara Sekular:Menegoisasikan Masa Depan Syariah. Bandung: Mizan.

Aspinall, E. (2005). Opposing Soeharto: Compromise,Resistance, and Regime Change in Indonesia. California: Stanford University Press.

Azim, F. (2013). Islam, Culture and Women in Asia: Complex Terrains,(:Routledge,2013),73-86. London and New York: Routledge.

Azra, A. (2006). Indonesia, Islam and Democracy: Dynamic in a Global Context. Jakarta: Solstice.

Beng-Huat, C. (2000). Consumption in Asia:Lifestyles and Identities. London: Routledge.

Breman, J. (2014). Keuntungan Kolonial dari Kerja Paksa: Sistem Priangan dari Tanam Paksa Kopi di Jawa,1720-1870. Jakarta: Yayasan Obor.

Budiman, A. (2002). Kebebasan, Negara, Pembangunan: Kumpulan Tulisan 1965-2005. Ciputat: Pustaka Alvabet.

Crouch, H. (1986). Militer dan Politik di Indonesia. Jakarta: Sinar Harapan.

Hasbullah, M. (2017). Islam dan Transformasi Masyarakat Nusantara. Jakarta: Kencana.

Horvatich, R. W. (1977). Islam in Era Of Nation-States: Politics and Religious Renewal in Muslim Southeast Asia. Hawai'i: University of Hawai'i Press.

J.A, D. (2006). Membaca Isu Politik. Yogyakarta: LKiS.

Jajat Burhanuddin, K. V. (2013). Islam in Indonesia:Contrasting Images and Intepretations. Amsterdam: Amsterdam University.

K.Mandal, A. H. (2003). Challenging Authoritarianisme in Southeast Asia Comparing Indonesia and Malaysia. New York: Routledge.

Meuleman, J. (2002). Islam in the Era of Globalization: Muslim Attitudes Towards Modernity and Identity. New York: Routledge.

Mufid, A. S. (2006). Tanglukan, Abangan,dan Tarekat: Kebangkitan Agama di Jawa. Jakarta: Yayasan Obor.

Mujani, S. (2007). Muslim Demokrat: Islam, Budaya, Demokrasi dan Partisipa- 
si Politik di Indonesia Pasca-Orde Baru. Jakarta: Gramedia.

P.Daniels, T. (2013). Performance, Popular Culture, and Piety in Muslum Southeast Asia. New York: Palgrave Macmillan.

R.Hadiz, D. B. (2014). ,Indonesian Politics and Society:A Reader. London and New York: Routledge.

Ricklefs. (2008). Sejarah Indonesia Modern 1200-2008. Yogyakarta: Serambi.

Rinakit, S. (2007). The Indonesian Military After The New Order. Copenhagen: NIAS Press.

Said, S. (2016). Menyaksikan 30 Tahun Kekuasaan Otoriter Soeharto. Yogyakarta: Mizan.

Syamsuddin, M. D. (2001). Islam dan Politik Era Orde Baru. Jakarta: Logos Wacana Ilmu.

Tagliacozzo, E. (2009). Political Islam in Post-Soeharto Indonesia:The Contest Between "Radical-ConservativeSoutheast Asia and the Middle East:Islam, Movement and the Longue Durée. Singapore: NUS.

Tebba, S. (1993). Islam Orde Baru:Perubahan Politik dan Keagamaan. Yogyakarta: Tiara Wacana.

Vatikiotis, M. R. (1993). Indonesian Politics under Suharto. New York: Routledge.

W.Hefner, R. (2000). Islam Pasar Keadilan:Artikulasi lokal, kapitalisme,dan Demokrasi. Yogayakarta: LKiS. 
